\author{
ACTA MYCOLOGICA \\ Vol. 43 (2): 181-191 \\ 2008
}

\title{
Fungi isolated from the rhizosphere of spring cruciferous plants
}

\author{
BARBARA MAJCHRZAK ${ }^{1}$, ADAM OKORSKI ${ }^{2}$ and BOGUSŁAW CHODOROWSKI ${ }^{1}$
}

${ }^{1}$ Department of Phytopathology and Entomology, University of Warmia and Mazury

Prawocheńskiego 17, PL-10-722 Olsztyn

${ }^{2}$ Department of Diagnostics and Plant Pathophysiology

University of Warmia and Mazury, Plac Łódzki 6, PL-10-727 Olsztyn, adam.okorski@uwm.edu.pl

Majchrzak B., Okorski A., Chodorowski B.: Fungi isolated from the rhizosphere of spring cruciferous plants. Acta Mycol. 43 (2): 181-191, 2008.

Fungal communities isolated from the rhizosphere of spring cruciferous plants were analysed in the study. It was found that the rhizosphere of crucifers was colonized primarily by fungi of the order Mucorales and of the genus Fusarium. Members of the genus Fusarium dominated in the rhizoplane. The roots of cruciferous plants secrete glucosinolates secondary metabolites known for their antifungal properties, thus affecting the communities of soil-dwelling fungi.

Key words: rhizosphere, cruciferous plants, fungi, Fusarium

\section{INTRODUCTION}

The soil provides habitat for both phytopathogenic and saprotrophic microorganisms, including bacteria, actinomycetes and fungi (Patkowska 1998). The rhizosphere, i.e. the zone that surrounds the roots of plants, plays a particularly important role due to its specific biological properties. It is teeming with a wide variety of microbes (Morgan et al. 2005), which can be divided into plant growth-promoting rhizobacteria (PGPR), deleterious rhizosphere microorganisms (DRMO) and neutral microorganisms - having no impact on plant growth (Sturz, Christie 2003). Under natural conditions, in undisturbed soil, the groups of beneficial and harmful microorganisms remain in the state of dynamic equilibrium. PGPR contribute to yield increment, usually resulting from higher nutrient availability and suppression of the growth and activity of deleterious microorganisms. DRMO compete with PGPR for food, thus negatively affecting crop development (Kurek, Kobus 1990). Due to their antagonist potential, soil microorganisms are able to colonize suitable niches. The antagonistic mechanisms include antibiosis, competition and mycoparasitism (hyperparasitism) (Sturz, Christie 2003). Many pathogens develop in the after-harvest residues of forecrops, so the type of forecrop may have a significant influence on the 
yield of successive crops (Bojarczuk, Bojarczuk 1988). Crucifers and legumes play a positive role in crop rotation because they improve the chemical, physical and biological properties of the soil (Majchrzak et al. 2002). Members of the family Brassicaceae are among the best forecrops, because they leave in the soil large amounts of after-harvest residues rich in glucosinolates and other secondary metabolites (Oleszek 1997). Moreover, they exert a positive effect on the health of successive crops (Majchrzak et al. 2004; Majchrzak et al. 2005).

The objective of this study was to determine the species composition of fungi isolated from the rhizosphere of selected cruciferous plants.

\section{MATERIALS AND METHODS}

The study was conducted during the years 1999-2001 at the Production-Experimental Station in Bałcyny near Ostróda (NE Poland), on the experimental plots of the Department of Plant Production, University of Warmia and Mazury in Olsztyn. The experiment was established on gray-brown podsolic soil developed from light silty clay, of quality class III a, of good wheat complex (1999 and 2000) or very good rye complex (2001). Crucifers were grown after spring wheat in 1999 and 2000, and after winter rapeseed in 2001. Mineral fertilizers (NPK) were applied at the following rates: $60-100: 40-60: 60-100 \mathrm{~kg} \bullet \mathrm{ha}^{-1}$, as recommended by the Institute of Soil Science and Plant Cultivation. The field trial was performed in a randomized block design, in three replications. The experimental factors were as follows:

factor I - cruciferous plants

- spring oilseed rape (Brassica napus f. annua) - cv. Margo,

- white mustard (Sinapis alba) - cv. Heter,

- Chinese mustard (Brassica juncea var. sareptana) - cv. Małopolska,

- radish (Raphanus sativus var. oleifera) - cv. Pegletta,

- false flax (Camelina sativa) - cv. Borowska,

- Spanish colewort (Crambe abyssinica)- cv. Borowski

factor II - years of the study

No fungicides were applied. Fungi were isolated from the rhizosphere, rhizoplane and roots of crops as described by Mańka (1974). The quantitative and qualitative composition of fungal communities was determined at full blooming $(\mathrm{BBCH}$ 65-69).

\section{RESULTS}

A total of 2929 fungal colonies belonging to 99 species and non-spore forming fungi were isolated from the rhizosphere of spring cruciferous plants over the three-year experimental period (Tab.1). Members of the order Mucorales dominated among them (48.96\% of all colonies). Representatives of the genus Rhizopus were isolated most frequently (15.94\%). Fungi of the genus Penicillium were also abundant $(12.43 \%)$. Antagonistic species, including the order Mucorales and the genera Gliocladium, Penicillium and Trichoderma, accounted for $66.58 \%$ of all isolates. The proportion of pathogens in the rhizosphere was $11.33 \%$, and the predominant role was played by species of the genus Fusarium (8.77\%), primarily F. solani, F. oxysporum and F. equiseti. 
The most diverse fungal community, composed of 637 colonies representing 44 species, was isolated from the rhizosphere of spring rape (Tab. 1). Mucorales (46.10\%), Fusarium (16.5\%), Penicillium (7.85\%) and Gliocladium (6.12\%) dominated among them. The fewest fungi (339 isolates belonging to 36 species) were detected in the rhizosphere of false flax. The most abundant among them were: Mucorales - 57.8\%, Acremonium - 9.44\% and Fusarium - 6.49\%. Fungi of the genus Fusarium were isolated least frequently from the rhizosphere of Spanish colewort (3.81\%). The genus Penicillium (270 isolates - 46.80\%) dominated in the rhizosphere of this crop. The rhizospheres of white mustard, Spanish colewort and radish were characterized by the lowest species diversity (35 fungal species each).

A total of 568 fungal colonies belonging to 80 species and non-spore forming fungi were isolated from the rhizoplane of spring cruciferous plants during the experimental period (Tab. 2). The most diverse fungal community, comprising 134 colonies representing 34 species, was isolated from the rhizosphere of spring rape. Members of the genera Fusarium (32.84\%) and Acremonium (21.64\%) as well as of the order Mucorales $(5.69 \%)$ dominated among them. The fewest fungi were isolated from the rhizoplane of Spanish colewort (73 isolates). This community, composed of only 24 species, was found to be the least diverse. The rhizoplane of this crop was mostly colonized by Gliocladium spp. (21.90\%), Aspergillus fumigatus (15.10\%) and Penicillium spp. (15.10\%). Representatives of the genus Fusarium constituted the least numerous group in the rhizoplane of Spanish colewort (6 isolates $-8.22 \%$ ).

\section{DISCUSSION}

Research results show that plants of the genus Brassicaceae grown as forecrops or ploughed in as green manure have a beneficial effect on the health of field crops (Majtahedi et al. 1991). The roots of crucifers secrete glucosinolates, which affect the soil microflora and help to control the occurrence of phytopathogens (Bones, Rossiter 1996; Kierkegaard, Sarwar 1998). Decomposition of the tissues of Brassicaceae as well as the production of glucosinolates followed by their hydrolysis lead to the formation of isothiocyanates (ITCs) - volatile substances considered to be biofumigants (Sarwar et al. 1998). According to Snapp et al. (2007) and Charron and Sam (1999), growing plants of the genus Brassicaceae as forecrops and leaving their remainders in the field inhibits the growth of such soil pathogens as Rhizoctonia solani and Pythium ultimum. Marwar and Lodha (2002) demonstrated that plants of the family Brassicaceae limited the occurrence of Fusarium oxysporum f. sp cumini.

In the present study fungi of the genus Fusarium were not abundant in the rhizosphere of crucifers. Their population was considerably greater in the rhizoplane. The soil environment of particular cruciferous plants was colonized by members of this genus to a different degree. Fusarium colonies were isolated most frequently from the rhizosphere and rhizoplane of spring oilseed rape, and least frequently from the rhizosphere and rhizoplane of Spanish colewort and false flax. Ishimoto et al. (2000) reported that fungi of the genus Fusarium isolated from the roots of crucifers showed high tolerance to glucosinolates, which may suggest that they acquired resistance to this group of substances through adaptation.

In the current experiment the rhizosphere of the Cruciferae was colonized by numerous representatives of the order Mucorales, dominated by members of the 


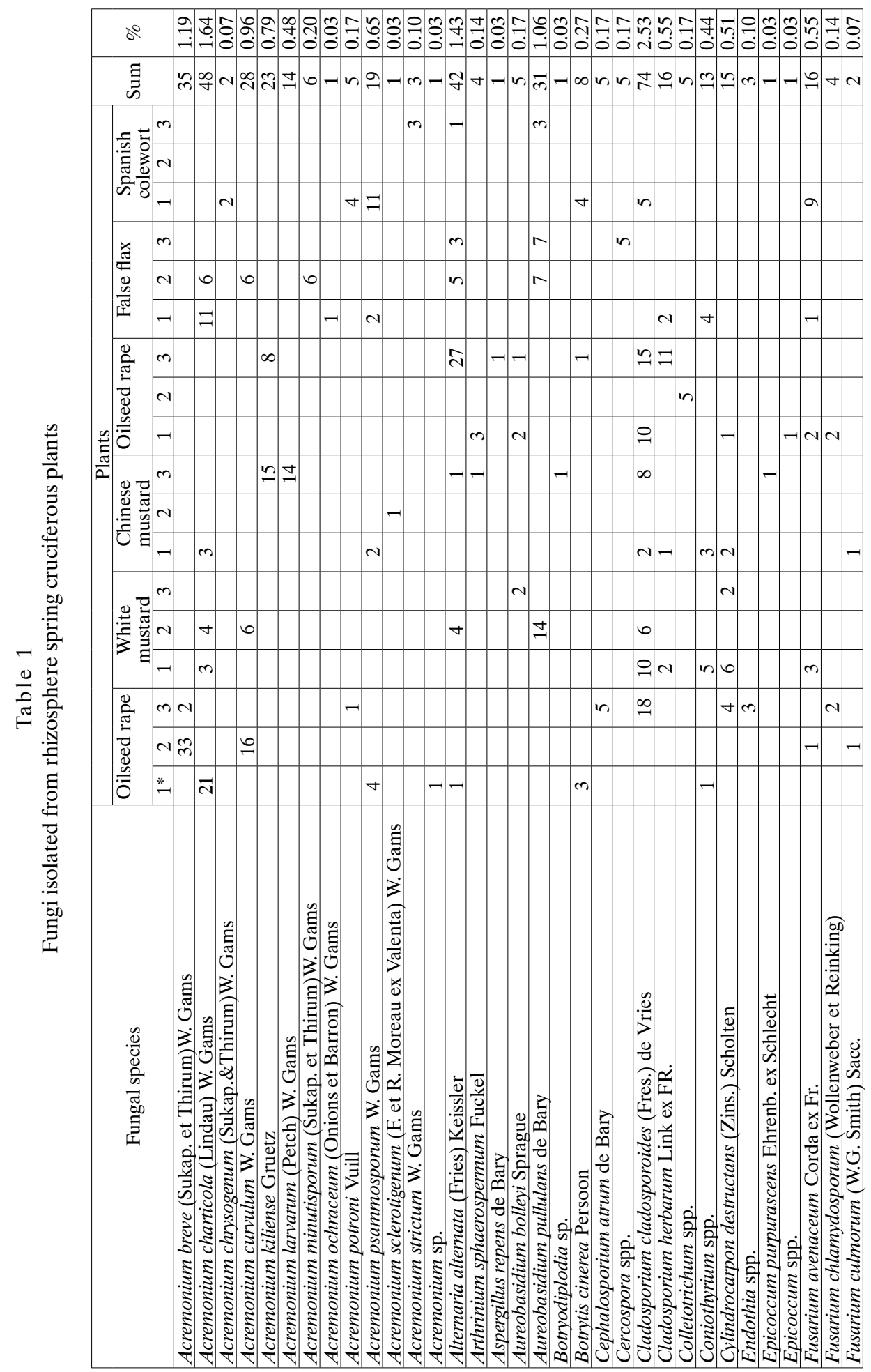




\begin{tabular}{|c|c|c|c|c|c|c|c|c|c|c|c|c|c|c|c|c|c|c|c|c|c|c|c|c|}
\hline$b^{\circ}$ & $\mid \begin{array}{c}\alpha \\
\text { d }\end{array}$ & 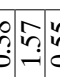 & $\hat{n}: \vec{n}$ & :ी: & & $\overrightarrow{0}$ & 8 & 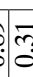 & $\underset{i}{\sigma} \mid \oint$ & & 8 & 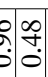 & $\hat{\widehat{c}}$ & & సి & $\begin{array}{c}0 \\
0 \\
0\end{array}$ & \begin{tabular}{l|l} 
\\
\hdashline
\end{tabular} & $\triangle 2$ & & & 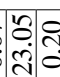 & & & \begin{tabular}{l|l}
8 \\
\hdashline
\end{tabular} \\
\hline 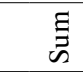 & & $=0$ & 영 & $\left.m\right|_{i n} ^{\infty}$ & & $\theta$ & $-\approx$ & & हิ & & -8 & & & & 0 & & $-r$ & 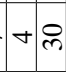 & $-\infty$ & & $\frac{n}{6}$ & $\circ=0 \hat{m}$ & & $\vec{m}-$ \\
\hline$\because=$ & $m$ & $m$ & & $m / \sigma$ & & & & & & & & 0 in & & $N$ & & & & $\mathrm{~N}$ & - & & $\stackrel{\infty}{=}$ & $n$ & & \\
\hline 考 & $\mathrm{N}$ & & & & & & & & & & & & & & & & & & 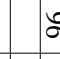 & & లి. & $\sim$ & & \\
\hline ns & - & & $-N$ & & & & $=$ & $\Rightarrow n$ & $\nabla$ & & 7 & -1 & & & & & & & & & & & & \\
\hline శ్ & $m$ & - & $a$ & & & & & & & & & & & & & & & & & & in & & & \\
\hline 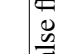 & $\mathrm{N}$ & $\mathrm{A} N$ & $\nabla$ & & & & & & & & . & & & & & $\mathrm{N}$ & & 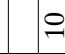 & - & & $\cong$ & & & \\
\hline$\Phi$ & - & & & - & & & & & & & & & & & & & & & & & & & & \\
\hline 总 & $m$ & & - & & & & $\sim$ & & & & & & -1 & & & & & & - & - & $=$ & & & \\
\hline $\bar{\Xi}$ & $\mathrm{N}$ & $n$ & - & & & & & & -1 & & & & & & & & & & $\gamma$ & & $\cong$ & & $\ln 7$ & $=$ \\
\hline$\stackrel{\infty}{0}$ & - & $\cong$ & $\nabla$ & $r$ & & & $\cong$ & & $N$ & & c & & & & & & & & & & $=$ & & & \\
\hline$\frac{\pi}{2}$ & $=m$ & & $\approx \approx$ & $\nabla$ & $+N$ & & & & & & & & $m$ & & & & & & & & & & & \\
\hline$\stackrel{\Xi}{\Xi}$ & S & & & & & & & & & & & & & & & & - & & & & กิ & & $\vec{\approx}$ & \\
\hline $0 \mathrm{E}$ & - & & - & - & & & $\sim$ & & & & - & & & & $N$ & & & & & & $\sim$ & & & \\
\hline 07 & $\theta$ & $\rightarrow$ & $\infty$ & $\sim$ & & & & & & & & & & & & & & & & & \pm & & & \\
\hline$\frac{\pi}{3}$ & $\stackrel{2}{2}$ & $m$ & $\mathrm{~N}$ & - & & $\nabla$ & & & $r$ & & & & & & & & & $\sim r$ & & & $\approx 0$ & & & $\Lambda$ \\
\hline & - & $\nabla$ & $N$ & 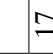 & & & & & $\beth$ & & $\curvearrowright$ & $N$ in & $N$ & & $\sim$ & & & & & & $r$ & $m$ & & \\
\hline 芯 & $m$ & ㅇ. & $-N$ & v & & & & t & & & & & - & & $\sim$ & & & & & & లి & & & \\
\hline$\overline{\mathscr{U}}$ & $\mathrm{N}$ & in & ते & - & & & -- & & 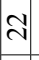 & & & & & & & - & r & $\cong$ & & ले & 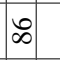 & & & $\infty$ \\
\hline है & $*$ & & 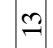 & $\infty$ & & & & & $=$ & -1 & in & n & & & & & & & & & & & & \\
\hline
\end{tabular}

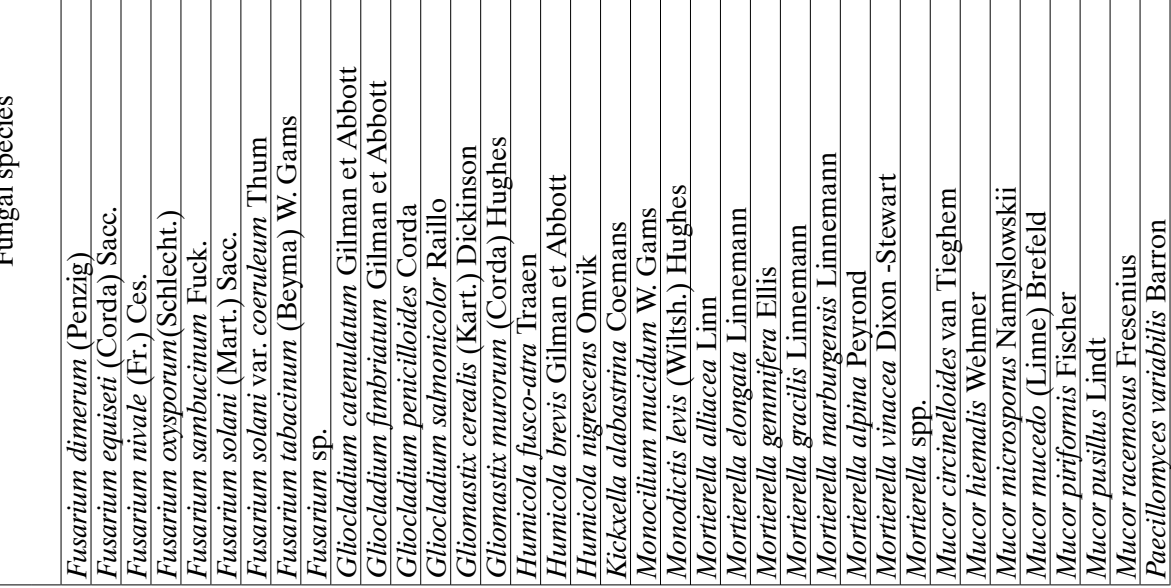




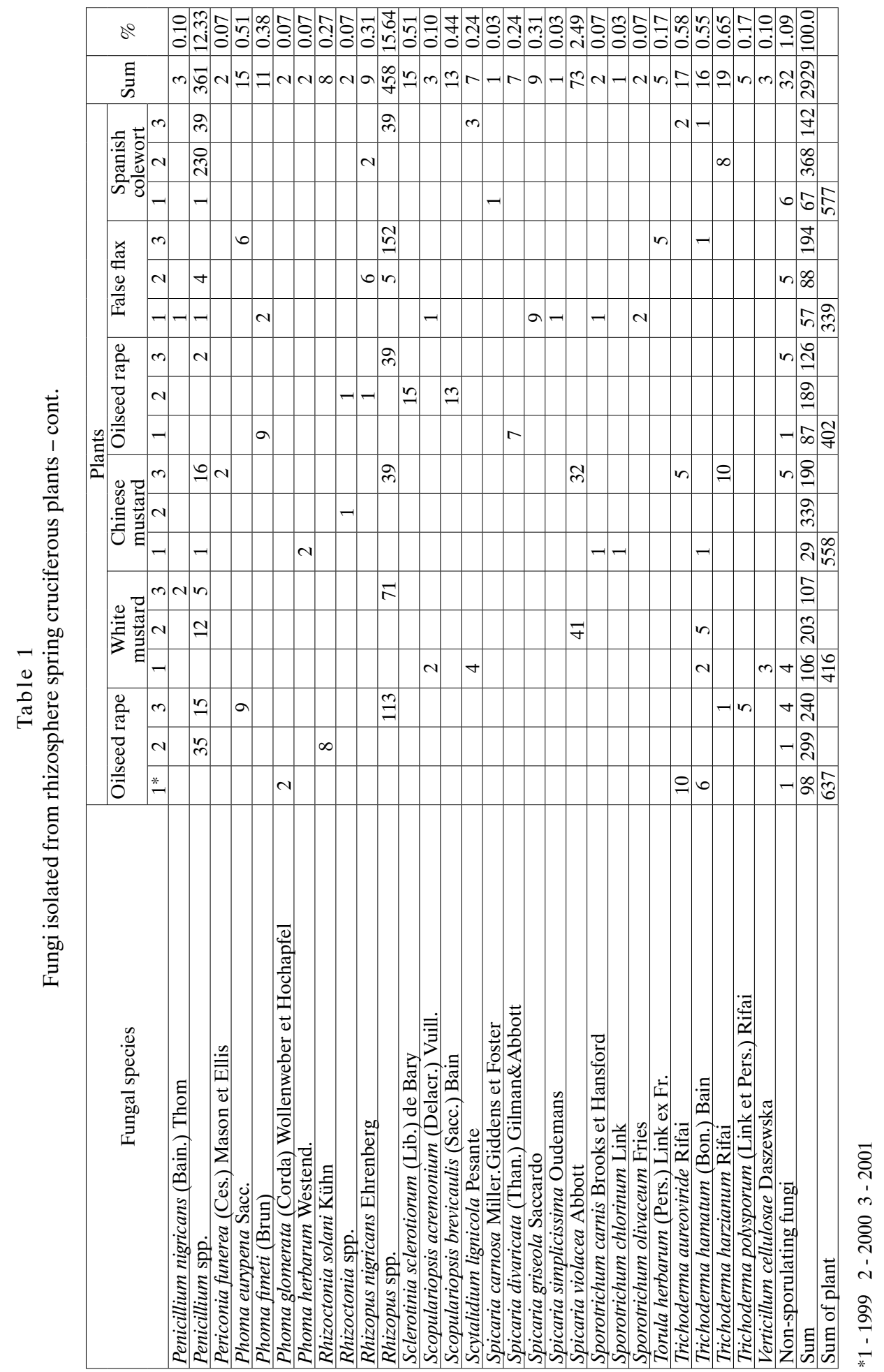




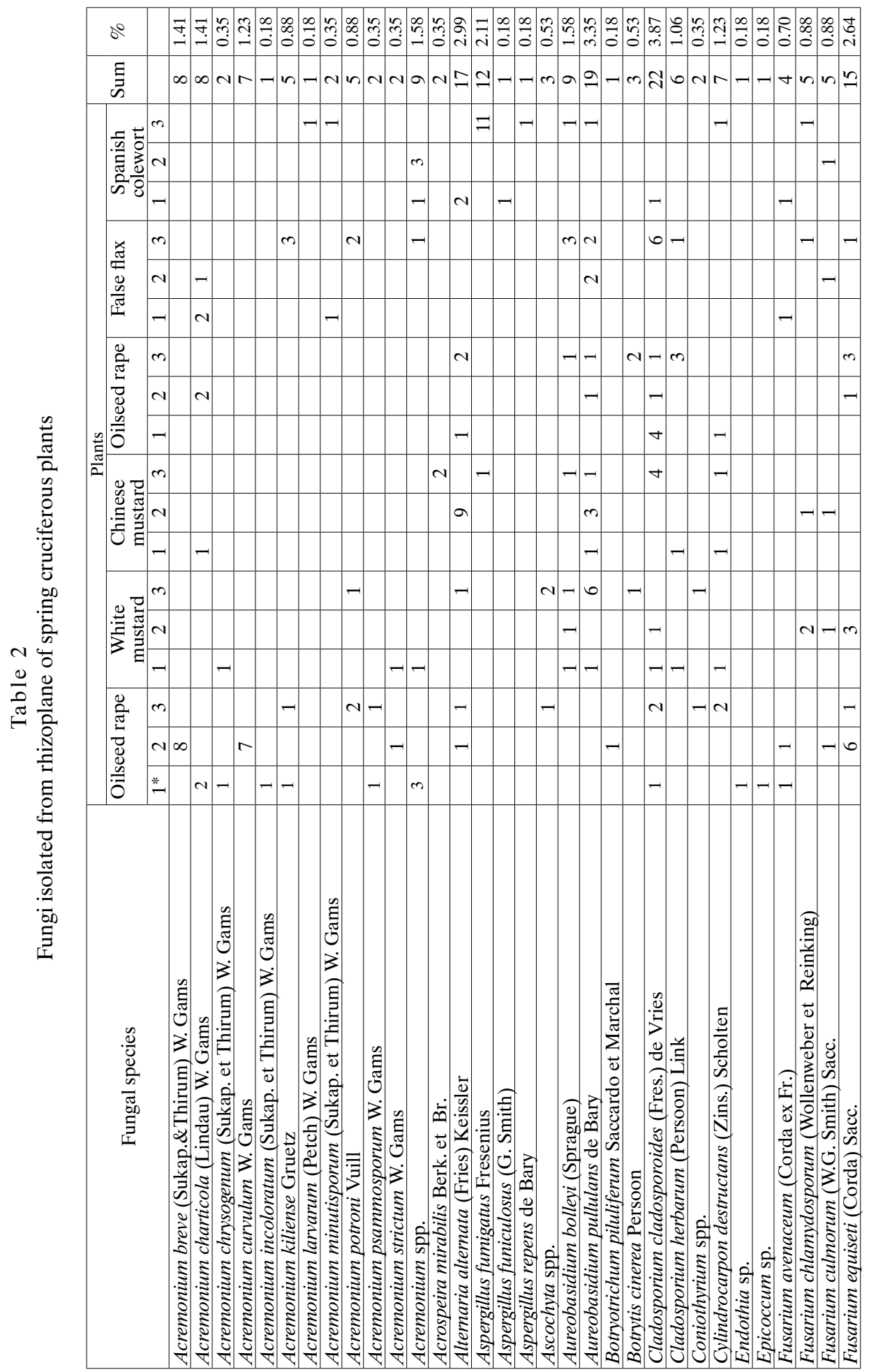




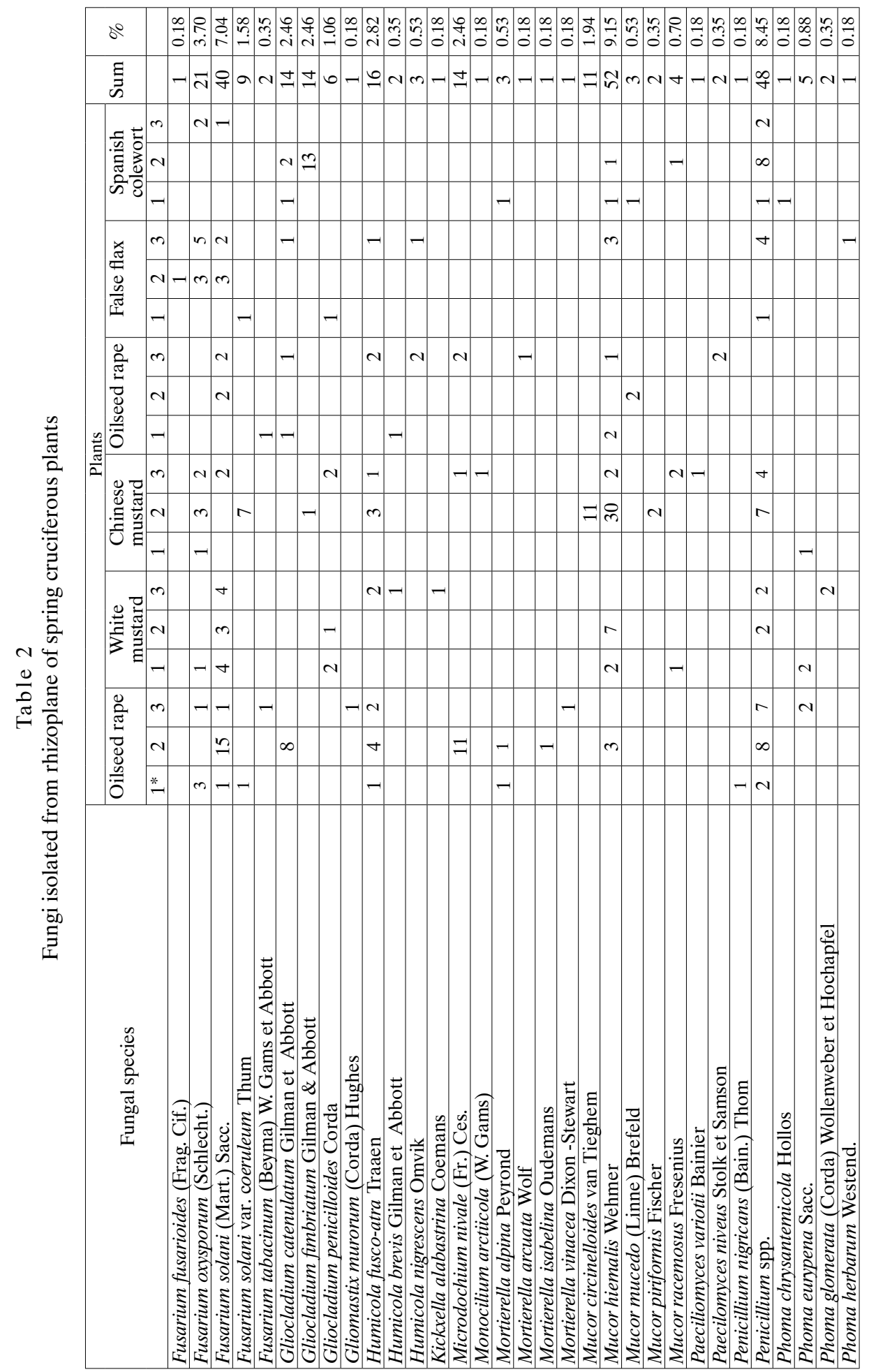


Fungi isolated from the rhizosphere
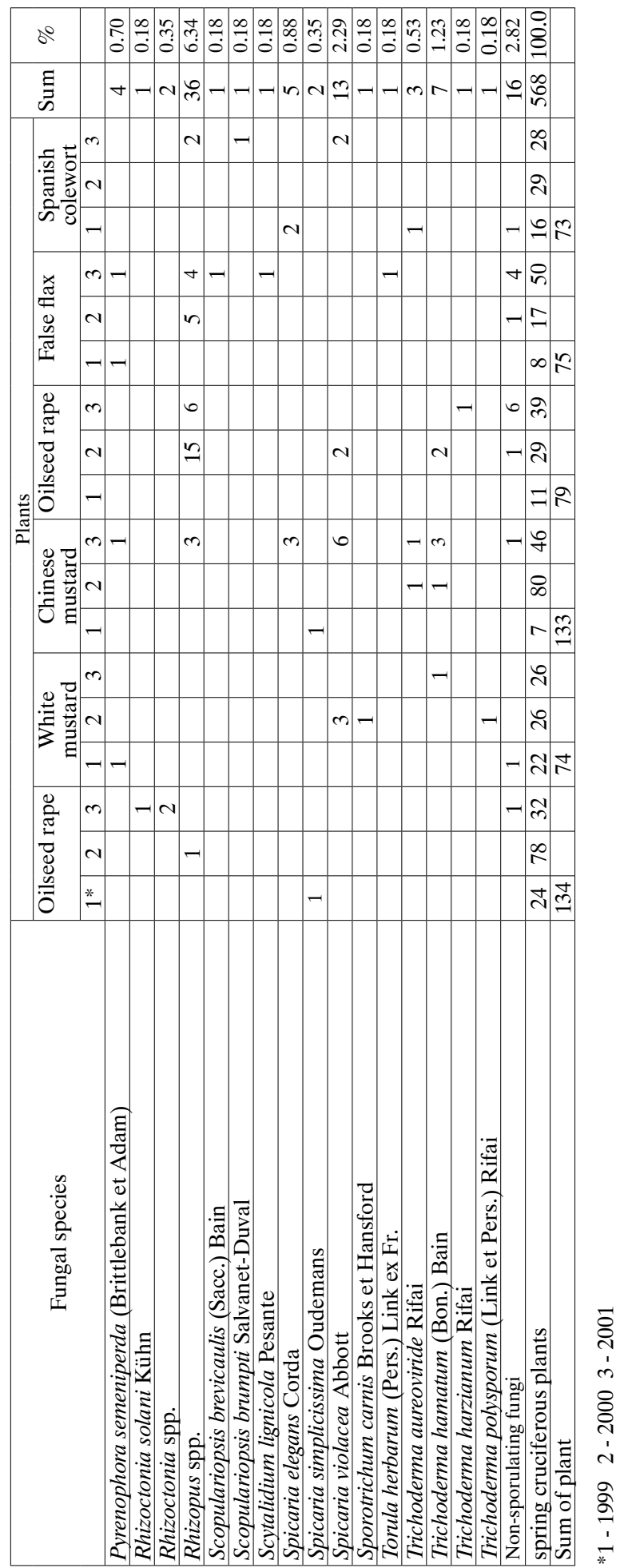
genus Rhizopus. Ishimoto et al. (2000) confirmed the predominant role of the genus Rhizopus in the rhizosphere of cruciferous plants. According to these authors, fungi of the genus Rhizopus showed significantly higher tolerance for glucosinolates than fungi of the genus Fusarium.

\section{CONCLUSIONS}

1. The largest and the most diverse fungal community was isolated from the soil environment of spring oilseed rape.

2. The fungal populations that colonized the rhizosphere and rhizoplane of Spanish colewort and false flax were found to be the smallest.

3. Members of the order Mucorales dominated in the soil environment of cruciferous plants.

4. Fungi of the genus Fusarium were isolated least frequently from the soil environment of Spanish colewort and most frequently from the soil environment of spring oilseed rape.

\section{REFERENCES}

Bojarczuk M., Bojarczuk J. 1988. Fitosanitarna ocena wartości przedplonów roślin zbożowych. Fragm. Agronom. 1(17): 5-23.

Bones A.M., Rossiter J.T. 1996. The myrosinase-glucosinolate system, its organisation and biochemistry. Physiol. Plant. 97:194-208.

Charron C.S., Sams C.E. 1999. Inhibition of Pythium ultimum and Rhizoctonia solani by shredded leaves of Brassica species. J. Am. Soc. Hortic Sci. 124:462-467.

Ishimoto H., Fukushi Y., Yoshida T., Tahara S. 2000. Rhizopus and Fusarium are selected as dominant fungal genera in rhizospheres of Brassicaceae. Journal of Chemical Ecology 26 (10): 2387-2399.

Kirkegaard J.A., Sarwar M. 1998. Biofumigation potential of brassicas. I. Variation in glucosinolate profiles of diverse field-grown brassicas. Plant Soil 201:71-89.

Kurek E., Kobus J. 1990. Korzystne i szkodliwe oddziaływanie mikroflory ryzosferowej na wzrost i rozwój roślin. Postępy Mikrobiologii 29 (1/2): 103-123.

Majchrzak B., Kurowski T.P., Karpińska Z. 2002. Zdrowotność jarych roślin krzyżowych a grzyby zasiedlające ich nasiona. Acta Agrobot. 55 (1): 199-210.

Majchrzak B., Okorski A., Chodorowski B. 2004. Zdrowotność korzeni i podstawy źdźbła pszenicy jarej uprawianej po różnych przedplonach. Annales UMCS 59(4): 1779-1788.

Majchrzak B., Chodorowski B., Okorski A. 2005. Choroby podstawy źdźbła pszenicy ozimej uprawianej po roślinach przedplonowych z rodziny Brassicaceae. Acta Agrobot. 59 (2): 307-318.

Majtahedi H., Santo G.S., Hang A.N., Wilson J.H. 1991. Suppression of root-knot nematode populations with selected rapeseed cultivars as green manure. J. Nematol. 23:170-174.

Mańka K.. 1974. Zbiorowiska grzybów jako kryterium oceny wpływu środowiska na choroby roślin. Zesz. Prob. Post. Nauk Roln. 160: 9-22.

Marwar R., Lodha S. 2002. Brassica amendments and summer irrigation for the control of Macrophomina phaseolina and Fusarium oxysporum f. sp cumini in hot arid region. Phytopathol. Mediterr 41:45-54.

Morgan J. A. W., Bending G. D., White P. J. 2005. Biological costs and benefits to plant-microbe interactions in the rhizosphere. Journal of Experimental Botany 56 (417): 1729-1739.

Oleszek W. 1997. Glukozynolany - występowanie i znaczenie ekologiczne. Wiadomości Bot. 39 (1/2): 49-58.

Patkowska E. 1998. Wpływ resztek roślinnych na zdrowotność i plonowanie soi. Roczn. Akad. Roln. Poznań, Ogrod. 27: 213-219.

Sarwar M., Kirkegaard J.A., Wong P.T.W., Desmarchelier J.M. 1998. Biofumigation potential of Brassicas. III. In vitro toxicity of isothiocyanates to soil-borne fungal pathogens. Plant Soil 201:103-112. 
Snapp S.S., Date K.U., Kirk W., O’Neil K., Kremen A., Bird G. 2007. Root, shoot tissues of Brassica juncea and Cereal secale promote potato health. Plant Soil. 294:55-72.

Sturz A. V., Christie B. R. 2003. Beneficial microbial allelopathies in the root zone: the management of soil quality and plant disease with rhizobacteria. Soil \& Tillage Research. 72: 107-123.

\section{Grzyby ryzosferowe jarych roślin kapustnych}

\section{Streszczenie}

W badaniach poddano analizie zbiorowiska grzybów ryzosferowych jarych roślin kapustnych. Ryzosferę roślin kapustnych zasiedlały przede wszystkim grzyby z rzędu Mucorales i rodzaju Fusarium. W ryzoplanie roślin znacznie częściej występowali przedstawiciele rodzaju Fusarium. Korzenie rośliny kapustnych wydzielają do gleby glukozynolany, wtórne metabolity o właściwościach antygrzybowych, w ten sposób być może wpływają na zbiorowiska grzybów zasiedlających środowisko glebowe roślin. 